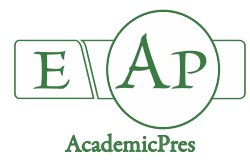

\title{
Phytochemical Composition and Antioxidant Activity of Various Grain Amaranth Cultivars
}

\author{
Andreea STĂNILĂ ${ }^{1}$, Bogdan CIOANCA², Zorița DIACONEASA ${ }^{1}$, \\ Sorin STĂNIL $\breve{A}^{3}$, Nicușor SIMA ${ }^{4}$, Rodica Maria SIMA ${ }^{2 *}$ \\ ${ }^{1}$ University of Agricultural Sciences and Veterinary Medicine Cluj-Napoca, Faculty of Food Science and Technology, 3-5 Mănăștur Street, \\ 400372, Cluj-Napoca,Romania; andreea.stanila@usamvcluj.ro; zorita.diaconeasa@gmail.com \\ ${ }^{2}$ University of Agricultural Sciences and Veterinary Medicine Cluj-Napoca, Faculty of Horticulture, 3-5 Mănăștur Street, 400372, \\ Cluj-Napoca,Romania; cioancabogdan@gmail.com;rodica.sima@usamvcluj.ro (*correspondingauthor) \\ ${ }^{3}$ University of Agricultural Sciences and Veterinary Medicine Cluj-Napoca, Faculty of Agriculture, 3-5 Mănăstur Street, 400372, \\ Cluj-Napoca, Romania; sorin.stanila@usamvcluj.ro \\ ${ }^{4}$ University of Agricultural Sciences and Veterinary Medicine Cluj-Napoca, Faculty of Animal Husbandry and Biotechnology, 3-5 \\ Mănăștur Street, 400372, Cluj-Napoca, Romania; nicusor.sima@usamvcluj.ro
}

\begin{abstract}
This study quantified differences in methanolic extracts composition among four grain amaranth cultivars (e.g. 'Hopy Red Dye', 'Amont', 'Plenitude', and 'Golden Giant') farmed under three planting conditions: no irrigation/no fertilization (NN), no irrigation/fertilization (NF), irrigation/no fertilization (IN). The study main outcomes were total flavonoids, polyphenols, antioxidant activity, and protein content. Antioxidant activity was assessed using two Single Electron Transfer (SET) based assays: the 2,2'-azinobis (3-ethylbenzothiazoline-6-sulfonic acid) radical cation decolorization assay (ABTS) and cupric reducing antioxidant capacity (CUPRAC). The total protein content was assessed by Gornall spectrophotometric method, the total flavonoid content (TFC) was determined using a colorimetric technique, while total polyphenols content (TPC) was assessed using the Folin-Ciocalteu method. Mean differences in outcomes were calculated using ANOVA and Dunnet's test for multiple comparisons. The findings revealed that TPC ranged from 5 to $18 \mathrm{mg}$ gallic acid equivalents (GAE)/100 g dry weight (DW), being highest in 'Plenitude' under NF conditions. The highest TFC (7.5 mg quercetin equivalent (QE)/100 g DW) and the highest protein content (37.25\%) were revealed for the 'Hopi Red Dye' cultivar under the NF planting conditions. Amaranth seeds represent a potential rich source of polyphenols and protein gluten-free compounds, with the 'Hopi Red Dye' representing the richest cultivar in such compounds. Fertilized and non-irrigated soil provided the optimal planting conditions across all amaranth cultivars.
\end{abstract}

Keywords: Amaranthus; antioxidant activity; flavonoids; manure; polyphenols; protein

\section{Introduction}

There is growing attention in the nutritional value of ancient cereals such as quinoa, amaranth, buckwheat, and chia (Alvarez-Jubete et al., 2010; Alonso-Miravalles and O'Mahony, 2018). This increased interest was partly due to the recognition of the health benefits (e.g. reduced food intolerance) these plants offered to people diagnosed with celiac disease, chronic disorders (e.g. cancer, diabetes), and those with allergies to typical cereals (Paśko et al., 2009). In addition to those mentioned before, grain amaranth was reported that it has been used as an effective alternative to drug therapy in people with hypertension and other cardiovascular diseases (Martirosyan et al., 2007; LawOgbomo and Ajayi 2009). Phytochemically, these pseudocereal seeds are a rich source of bioactive compounds with high nutritional qualities, including polyphenols (phenolic acids, anthocyanins or flavonoids), amino acid, vitamins and mineral elements (e.g. Calcium (Ca), Ferrum (Fe)) (Gorinstein et al., 2002). Several studies (Alvarez-Jubete et al., 2010; Venskutonis and Kraujalis, 2013; AlonsoMiravalles and O'Mahony, 2018) have documented the valuable nutritional properties of amaranth seeds (including about $15 \%$ protein, $60 \%$ starch and $8 \%$ fat), estimated to be superior to more common grains such as wheat, corn or

Received: 04 Oct 2019. Received in revised form: 10 Nov 2019. Accepted: 29 Nov 2019. Published online: 10 Dec 2019. 
1154

oats. Regarding the protein content, amaranth seeds are an excellent source of adequate balance of amino acids, with high lysine content (Lopez et al., 2011; Perales-Sánchez et al., 2014). Moreover, amaranth seeds are rich in polyphenolic compounds (e.g. phenolic acids and flavonoids) and polyunsaturated fatty acids or squalene (Berger et al., 2003; Lopez et al., 2011; Hlinková et al., 2013). Due to amaranth plants resistance to harsh climatic conditions, diseases and pest, this crop is very easy to establish and gained popularity in many countries from Africa to India, Europe or China (Prakash and Pal, 1991; Peiguo et al., 2003).

Despite increased recognition of its nutritional values, our knowledge of which amaranth cultivars provide optimal nutritional benefits when cultivated outside their natural habitat are incomplete. In addition, soil conditions (e.g. fertilization or irrigation) may alter the productivity, nutritional distribution, and content within specific amaranth cultivars. For commercial production, cultural practices including application of organic manure and fertilizers for improving growth and yield of crop are desirable (Law-Ogbomo and Ajayi, 2009). There is, however, limited understanding of how planting conditions influence the combination of specific proteins and polyphenols among specific amaranth cultivars. In this context, the aim of our study was to compare how planting conditions influence the phytochemical composition (e.g. antioxidant potential, total polyphenols, flavonoid and protein content) among four amaranth cultivars, including 'Hopy Red Dye', 'Amont', 'Plenitude', and 'Golden Giant'. Our study main (null) hypothesis was that planting conditions would have no influence on the phytochemical composition for the four amaranth cultivars.

\section{Materials and Methods}

\section{Plant materials and growth conditions}

The experiment was conducted in 2016, in the Alba County, a geographically varied county in the eastern central zone of Transylvania, Romania. The Alba county climate is temperate, with the average temperature at around $9.7{ }^{\circ} \mathrm{C}$, and average precipitations at around 753 $\mathrm{mm}$. For the present study, amaranth cultivars' seeds were sown in March and harvested in September 2016. Four cultivars, belonging to cruenthus and bypochondriacus species of Amaranthus, were used: 'Amont' (Amaranthus cruenthus), 'Golden Giant' (Amaranthus bypochondriacus), 'Hopi Red Dye' (Amaranthus bypochondriacus), and 'Plenitude' (Amaranthus hypochondriacus). Amaranth cultivars were cultivated on chernozem soil under different fertilization and irrigation conditions including: no irrigation/no fertilization ( $\mathrm{NN}$, considered as control), no irrigation/fertilization (NF), irrigation/no fertilization (IN). Soil fertilization involved the use of cattle manure (20.000 kg.ha ${ }^{-1}$, applied and incorporated into the soil in autumn by ploughing), while irrigation aimed to maintain soil moisture to the field capacity during vegetation period. The experiment was implemented in four plots (one for each cultivar: 'Plenitude', 'Golden Giant', 'Amont', and 'Hopi Red Dye'), with each plot (cultivar) divided into three subplots according to the study specific fertilization and irrigation conditions (NN, NF, and IN). The air-dried seeds were deposited in paper bags and stored in the dark at laboratory's temperature $\left(25^{\circ} \mathrm{C}\right)$.

\section{Study measures}

The study employed four main continuous outcome measures including total phenolic content, flavonoids content, antioxidant activity, and total protein content.

\section{Polyphenolics extractions}

Powdered samples of amaranth seeds were extracted using a protocol published previously (Nana et al., 2012). Briefly, the extraction was done by mixing the plant material in $1 / 10(\mathrm{w} / \mathrm{v}$ ratio) for 24 hours at room temperature. The extraction solvent consisting of methanol, $0.16 \mathrm{M}$ hydrochloric acid, and water, mixed in proportion $8: 1: 1$. The obtained extracts were filtered and then concentrated at $35^{\circ} \mathrm{C}$ under reduced pressure (Rotavap Laborata 4010 Digital, Heidolph). Next, the samples were solubilized in a known amount of methanol, filtered through $0.45 \mu \mathrm{m}$ Millipore nylon filter and used for prior analysis.

\section{Determination of total phenolic content}

Total polyphenols of analyzed samples were determined using Folin-Ciocalteu colorimetric method adapted for 24 well plate (Singleton et al., 1999; Rabie et al., 2015). Briefly, the oxidation of the samples $(25 \mu \mathrm{L})$ was carried out by the Folin-Ciocalteu reagent $(120 \mu \mathrm{L})$ and the neutralization was made with $\mathrm{Na}_{2} \mathrm{CO}_{3}(340 \mu \mathrm{L})$ after $5 \mathrm{~min}$. The samples absorbance was measured at $750 \mathrm{~nm}$ after $90 \mathrm{~min}$, at room temperature. The results were expressed as mg of GAE/100 g DW. Each determination was carried out in triplicate.

\section{Determination of total flavonoid content}

The total flavonoid content was determined using a colorimetric technique (Kim et al., 2003). Initially, the samples were mixed with $300 \mu \mathrm{L} \mathrm{NaNO}_{2}$ (5\%) and the obtained mixture was kept at room temperature for $5 \mathrm{~min}$. Next, $300 \mu \mathrm{L} \mathrm{AlCl}_{3}(10 \%)$ were added to the mixture, followed by $2 \mathrm{~mL}$ of $\mathrm{NaOH}(1 \mathrm{~N})$. The final solution was mixed and the absorbance was measured against blank at $510 \mathrm{~nm}$. Total flavonoid content was expressed as $\mathrm{mg}$ $\mathrm{QE} / 100 \mathrm{~g}$ DW. Each determination was carried out in triplicate.

\section{Determination of antioxidant activity}

In order to quantify potential variation in antioxidant activity in the four cultivars, the study used two techniques: the 2,2'-azinobis(3-ethylbenzothiazoline-6-sulfonic acid) radical cation decolorization assay (ABTS) and the cupric reducing antioxidant capacity (CUPRAC).

\section{ABTS}

The $\mathrm{ABTS}^{+}$solution was prepared by mixing $7 \mathrm{mM}$ ABTS stock solution with $2.45 \mathrm{mM}$ potassium persulfate (final concentration) for $12-16 \mathrm{~h}$, in the dark, at room temperature. Before usage, the $\mathrm{ABTS}^{+}$working solution was prepared by diluting the stock solution with EtOH to an absorbance of $0.70 \pm 0.02$ at $734 \mathrm{~nm}$. The samples and standards $(20 \mu \mathrm{l})$ were combined with the $\mathrm{ABTS}^{+}$working 
solution $(170 \mu \mathrm{ll})$ in 96-well microplate. After $6 \mathrm{~min}$ of incubation at room temperature, the absorbance was read at $734 \mathrm{~nm}$ using the microplate reader HT BioTek Synergy (BioTek Instruments, USA). The measurements were expressed as micromoles Trolox equivalents per gram sample $(\mathrm{TE} \mu \mathrm{mol} / \mathrm{g})$.

\section{CUPRAC}

The modified cupric reducing antioxidant capacity (CUPRAC) method was applied to evaluate the antioxidant potential of the study cultivars (Çekiç et al., 2009). Namely, one milliliter of $1.0 \times 10^{-2} \mathrm{M} \mathrm{CuCl}_{2} \cdot \mathrm{H}_{2} \mathrm{O}, 1$ $\mathrm{mL}$ of $7.5 \times 10^{-3} \mathrm{M}$ Neocuproine, and $2 \mathrm{~mL}$ of $\mathrm{pH} 7.0$ urea buffer were mixed together. To this mixture we have added $(1.0-\mathrm{x}) \mathrm{mL}$ of $\mathrm{pH} 8$ standard buffer and $(\mathrm{x}) \mathrm{mL}$ sample or standard antioxidant solution or a mixture of both. The final mixture at $5.0 \mathrm{~mL}$ total volume was kept at room temperature for exactly $30 \mathrm{~min}$, and the absorbance was recorded against a blank at $450 \mathrm{~nm}$. The measurements were expressed as micromoles Trolox equivalents per gram sample $(\mathrm{TE} \mu \mathrm{mol} / \mathrm{g})$.

\section{Determination of protein content}

Protein content was evaluated using a spectrophotometric method, Gornall assay. The powdered samples $(40 \mathrm{mg})$ were mixed with $1 \mathrm{~mL} \mathrm{NaOH} 1 \mathrm{~N}$ and boiled for 10 minutes. Afterward $4 \mathrm{ml}$ of Gornall reactive was added; the samples were filtered and incubated at room temperature for 20 minutes. Finally, the samples were centrifuged at $12000 \mathrm{rpm}$ for 5 minutes and the absorbance of the supernatant was recorded against a blank at $450 \mathrm{~nm}$. The measurements were expressed as percentages using a standard curve of albumin.

\section{Statistical analysis}

Data were expressed as mean and related standard error for each sample, analyzed three times. Analysis of variance (ANOVA) and Dunnett's multiple comparisons test were used to compare differences in antioxidant activity, total polyphenols, flavonoids, and proteins content among the four amaranth cultivars planted in the three irrigation and fertilization conditions (e.g. NN, NF, IN), using NN as the reference group. Additional analyses compared differences in study outcomes between the four cultivars within each irrigation and fertilization condition. The reference category for amaranth cultivars was the 'Plenitude' cultivar. All study analyses were performed using the Prism software.

\section{Results}

Total polyphenols content (TPC)

The amount of polyphenols within the amaranth cultivars (Table 1 and Fig. 1) ranged from 5.0 to $18.5 \mathrm{mg}$ GAE $/ 100 \mathrm{~g}$ DW. Across the three planting conditions, the highest concentration of polyphenols was found in the 'Plenitude' cultivar (17 (NN), 18.5 (NF) and 16 (IN) mg GAE/100 g DW) followed by 'Hopi Red Dye' (12.3 (NN), 13.6 (NF) and 12.6 (IN) $\mathrm{mg}$ GAE/100 g DW). No irrigation/fertilization soil condition led to the highest polyphenols across all cultivars, with the exception of 'Amont' cultivar, where the irrigation/no fertilization combination resulted in the highest polyphenols content (7.8 mg GAE/100 g DW).

\section{Total flavonoid content (TFC)}

The total flavonoid content values evaluated by spectrophotometric method for all amaranth cultivars were

Table 1. Mean and associated standard error for total polyphenols ( $\mathrm{mg} \mathrm{GAE} / 100 \mathrm{~g} \mathrm{DW}$ ) and flavonoids (mg QE/100 g DW) content associated with specific cultivars and fertilization/irrigation conditions

\begin{tabular}{|c|c|c|c|c|}
\hline \multirow{2}{*}{$\begin{array}{c}\text { Fertilization/ } \\
\text { irrigation treatment }\end{array}$} & \multicolumn{4}{|c|}{ Cultivar } \\
\hline & 'Plenitude' & 'Golden Giant' & 'Amont' & 'Hopi Red Dye' \\
\hline \multicolumn{5}{|c|}{ Total polyphenols content } \\
\hline No irrigation/No fertilization & $17 \pm 0.2$ & $5 \pm 0.4$ & $6.9 \pm 0.23$ & $12.3 \pm 0.3$ \\
\hline No irrigation/Fertilization & $18.5 \pm 0.3$ & $7.2 \pm 0.2$ & $7.3 \pm 0.3$ & $13.6 \pm 0.12$ \\
\hline Irrigation/No fertilization & $16 \pm 0.3$ & $5.6 \pm 0.5$ & $7.8 \pm 0.26$ & $12.6 \pm 0.3$ \\
\hline \multicolumn{5}{|c|}{ Total flavonoids content } \\
\hline No irrigation/No fertilization & $1.8 \pm 0.15$ & $2.5 \pm 0.2$ & $3.2 \pm 0.3$ & $5.6 \pm 0.2$ \\
\hline No irrigation/Fertilization & $2.9 \pm 0.25$ & $3.0 \pm 0.2$ & $4.3 \pm 0.2$ & $7.5 \pm 0.3$ \\
\hline Irrigation/No fertilization & $2.6 \pm 0.2$ & $2.6 \pm 0.3$ & $3.6 \pm 0.4$ & $6.5 \pm 0.3$ \\
\hline
\end{tabular}

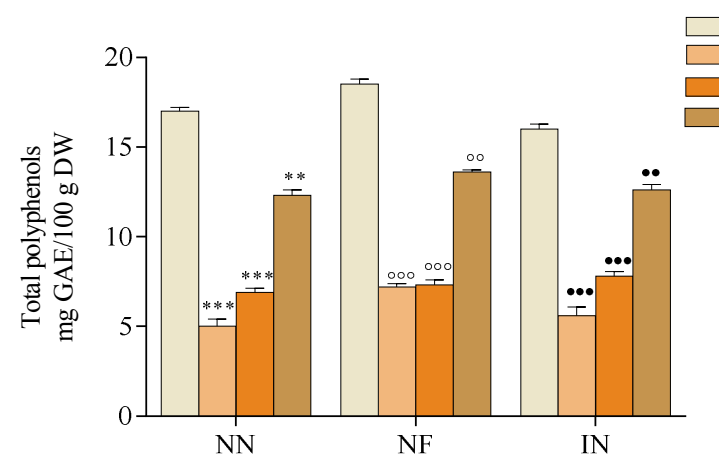

Fig. 1. Differences in total polyphenols content (mg GAE/100 g DW) between the amaranth cultivars by planting condition: $\mathrm{NN}$ - no irrigation/no fertilization, NF - no irrigation/fertilization, IN- irrigation/no fertilization 
1156

in the range of 1.8-7.5 mg QE/100 $\mathrm{g} \mathrm{DW}$ (Table 1 and Fig. 2). Within each cultivar, the highest content was obtained for the NF condition (2.9 ('Plenitude') to 7.5 ('Hopi Red Dye') QE/100 g DW) and the lowest within the NN condition (1.8 ('Plenitude') to 5.6 ('Hopi Red Dye') $\mathrm{QE} / 100 \mathrm{~g} \mathrm{DW})$. Across all three planting conditions, the highest value was observed for 'Hopi Red Dye' cultivar and the lowest value for the 'Plenitude' cultivar.

\section{Antioxidant activity \\ ABTS assay}

All methanolic extracts were found to scavenge ABTS radical. This potential scavenging is an important property of antioxidants. Also, in this case a significant increase for the samples which were no irrigated but fertilized was observed (Fig. 3). 'Hopi Red Dye' cultivar extract showed the highest antioxidant activity across all three planting conditions (49 (NN); 52 (NF); 47(IN) $\mu \mathrm{M}$ TE/g). The NF condition produced the highest antioxidant activity across all four cultivars.

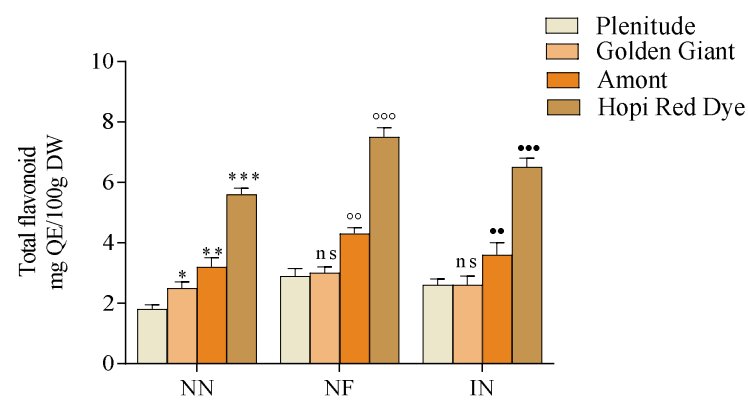

Fig. 2. Differences in total flavonoids content (mg QE/100 g DW) across the amaranth cultivars by planting condition: NN - no irrigation/no fertilization, NF - no irrigation/fertilization, IN- irrigation/no fertilization

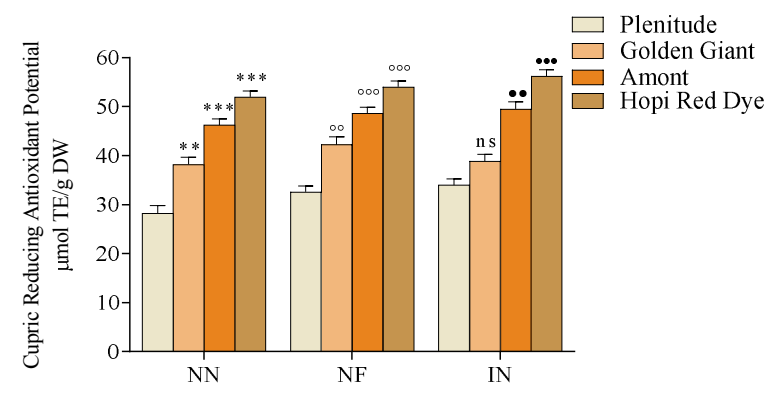

Fig. 4. Differences in antioxidant activity $(\mu \mathrm{M} \mathrm{TE} / \mathrm{g})$ within the amaranth seeds using the CUPRAC assay: NN - no irrigation/no fertilization, NF - no irrigation/fertilization, IN- irrigation/no fertilization

\section{CUPRAC assay}

As illustrated in Fig. 4, the antioxidant activity varied slightly when using the CUPRAC technique. Specifically, by the CUPRAC assay the highest antioxidant activity was observed within the 'Hopi Red Dye' cultivar in the IN soil condition (56 $\mu \mathrm{M} \mathrm{TE} / \mathrm{g}$ ) and the lowest among the 'Plenitude' cultivar in the NN soil condition $(28 \mu \mathrm{M}$ TE/g). In contrast to the ABTS method, the IN conditions led to the highest antioxidant activity across the study cultivars with the exception of 'Golden Giant', where NF soil condition was associated with the highest antioxidant activity ( $42 \mu \mathrm{M}$ TE/g).

\section{Protein content}

The protein content (Fig. 5) varied between the samples (12.34\%-37.25\%), with the highest one being observed within the 'Hopi Red Dye' cultivar, followed by 'Amont', 'Golden Giant' and 'Plenitude'. The NF planting condition resulted in the highest total protein content across all four cultivars, with the lowest being observed in the IN condition.

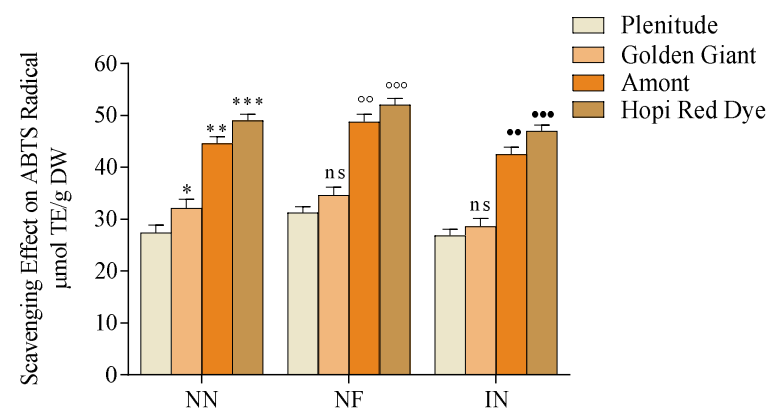

Fig. 3. Differences in antioxidant activity ( $\mu \mathrm{M} \mathrm{TE} / \mathrm{g})$ within the amaranth cultivars by planting conditions using the ABTS assay: NN - no irrigation/no fertilization, NF - no irrigation/fertilization, IN - irrigation/no fertilization

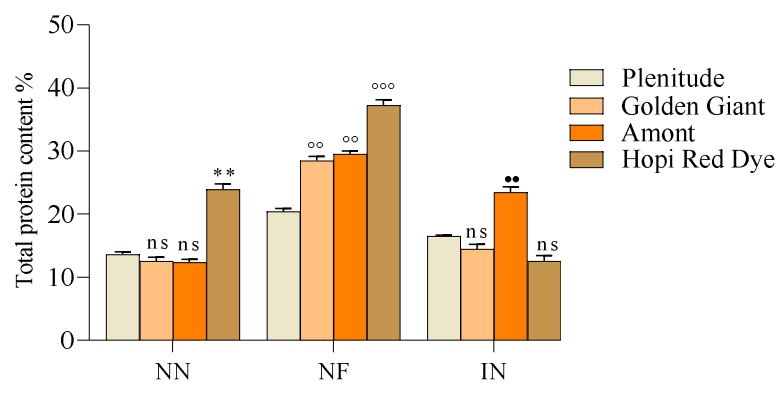

Fig. 5. Differences in total protein content (\%) across the amaranth cultivars by planting condition: NN - no irrigation/no fertilization, NF - no irrigation/fertilization, IN- irrigation/no fertilization 
Correlations between total polyphenols content (TPC), total flavonoids content (TFC) and antioxidant assays ABTS, CUPRAC

In this study significant correlations were found between TPC, TFC and antioxidant activity across all the cultivars studied. The results for Pearson correlations (Table 2) revealed that there were differences between ABTS and CUPRAC assays regarding antioxidant activity assessment for the four amaranth cultivars studied. An explanation for the differences between the two assays could be given if we take into account the ratio total flavonoids content/total polyphenols content (TFC/TPC), values considered as averages for each amaranth cultivar studied, across all the tree planting conditions (Table 3). Pearson's linear relationships analysis revealed good correlations between total polyphenols vs. ABTS assay for 'Plenitude' cultivar $\left(R^{2}=0.915\right)$, which had a higher polyphenols content comparing with flavonoids (TFC/TPC, $\mathrm{R}=0.14$ ). For 'Golden Giant' and 'Amont' cultivars where flavonoids represent the majority from the phenolic compounds $(\mathrm{R}=0.45$, respectively 0.50$)$ were obtained lower correlations $\mathrm{R}^{2}=0.399$, respectively $\mathrm{R}^{2}=0.149$. The TFC/TPC ratio indicates the share of flavonoids in total polyphenols from amaranth seeds. The data presented in Table 3 outline that the richest phenolic sources are
'Plenitude' and 'Hopi Red Dye' cultivars, but flavonoids had the smaller share in cultivar 'Plenitude'. The TFC/TPC ratio also indicates which phenolic classes are involved more in antioxidant activity. In 'Golden Giant', 'Amont' and 'Hopi Red Dye' cultivars case, flavonoids are more responsible for antioxidant activity compared with other phenolic compounds. Antioxidant activity of total polyphenols determined by CUPRAC assay gave positive correlations for all cultivars studied, but better results were obtained for the cultivars with higher flavonoid content 'Golden Giant' $\left(\mathrm{R}^{2}=0.988\right)$ and 'Amont' $\left(\mathrm{R}^{2}=0.906\right)$. Regarding total flavonoids correlations versus ABTS and CUPRAC assays, in all cultivars were obtained positive correlations, better results being obtained for 'Hopi Red Dye' cultivar, which had the highest ratio TFC/TPC.

Correlations between protein content and planting conditions

In this study significant correlations were found between protein content and planting conditions across all of the cultivars studied. Pearson's linear relationships analysis (Fig. 6) revealed good correlations $\left(\mathrm{R}^{2}=0.6834\right)$ between NN condition vs. NF condition, but weak and negative correlations $\left(\mathrm{R}^{2}=0.241\right)$ between $\mathrm{NN}$ condition vs. IN condition.

Table 2. Pearson correlation for total polyphenols content (TPC), total flavonoids content (TFC), and antioxidant activity for the four amaranth cultivars

\begin{tabular}{|c|c|c|c|c|c|c|c|c|}
\hline & \multicolumn{4}{|c|}{ Total polyphenols content } & \multicolumn{4}{|c|}{ Total flavonoids content } \\
\hline & 'Plenitude' & 'Golden Giant' & 'Amont' & 'Hopi Red Dye' & 'Plenitude' & 'Golden Giant' & 'Amont' & 'Hopi Red Dye' \\
\hline ABTS & 0.915 & 0.399 & 0.149 & 0.652 & 0.399 & 0.475 & 0.584 & 0.384 \\
\hline CUPRAC & 0.014 & 0.988 & 0.906 & 0.032 & 0.769 & 0.429 & 0.332 & 0.891 \\
\hline
\end{tabular}

Note: ABTS-2,2'-azinobis(3-ethylbenzothiazoline-6-sulfonic acid) radical cation decolorization assay; CUPRAC-Cupric reducing antioxidant capacity

Table 3. The ratio between total polyphenols $(\mathrm{mg} \mathrm{GAE} / 100 \mathrm{~g} \mathrm{DW})$ and total flavonoids ( $\mathrm{mg} \mathrm{QE} / 100 \mathrm{~g} \mathrm{DW})$ content, considered as average of the three planting conditions for each amaranth cultivar

\begin{tabular}{cccc}
\hline & Total polyphenols content (TPC) & Total flavonoids content (TFC) & TFC/TPC \\
\hline 'Plenitude' & 17.16 & 2.43 & 0.14 \\
'Golden Giant' & 5.93 & 2.70 & 3.70 \\
'Amont' & 7.33 & 0.45 & 0.50 \\
'Hopi Red Dye' & 12.83 & 0.53 & 0.51 \\
\hline
\end{tabular}

Correlation protelo content NN/NF/TN systens;

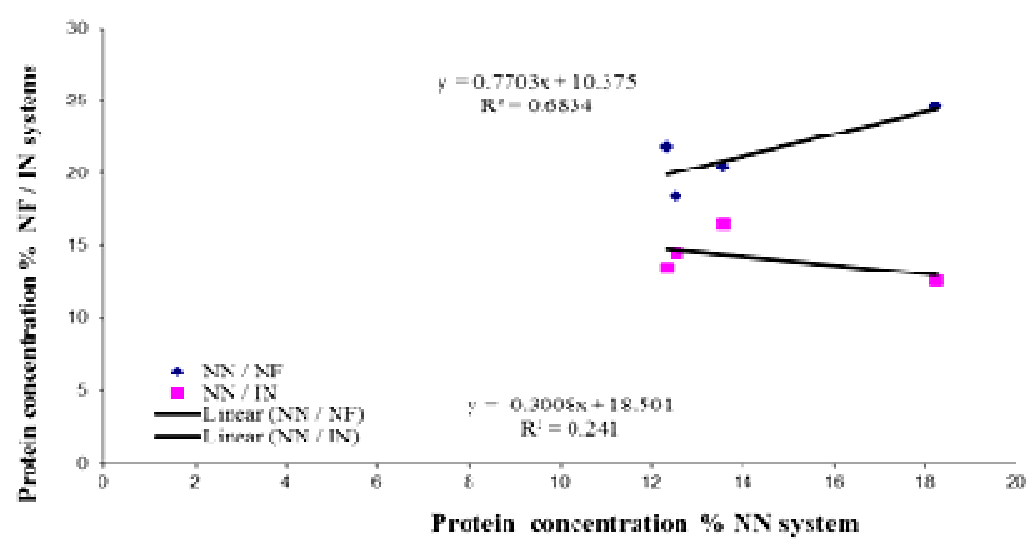

Fig. 6. Correlations protein content versus NN/NF and NN/IN fertilization/irrigation treatments 
1158

\section{Discussion}

The present study aimed to quantify the influence of specific soil conditions on the production quality of four amaranth cultivars. Our study documented that the 'Plenitude' cultivar had the highest concentration of polyphenols (e.g. flavonoids and phenolic) compounds. With regards to antioxidant activity and protein content, the 'Hopi Red Dye' cultivar revealed the highest values, followed by the 'Amont' cultivar. Notably, the highest concentration of polyphenols, proteins, and antioxidant activity were observed under NF soil conditions.

The European Commission has recently issued a set of recommendations to reduce the vulnerability of agricultural products to increased draught conditions, given recent climate changes. Specifically, it was recommended that EU countries should favour those cultivars that are best adapted to conditions of high temperatures and reduced yearly rainfalls. Within the context of Romania current climate changes and the present study planting conditions, the 'Plenitude' and 'Hopi Red Dye' amaranth cultivars produced seeds with the highest content of polyphenols and antioxidant activity under NF planting conditions. Studies using different amaranth cultivars may lead to variation in findings and this remains an area in need of future research.

Phenolic acids and flavonoids are two important groups of plant secondary compounds, which are suggested to protect plants against abiotic stress through their antioxidant properties to eliminate reactive oxygen species before they oxidize cell walls and membranes (Shamloo et al., 2017). The concentrations of various secondary plant products are strongly dependent on the growing conditions and have impact on the metabolic pathways responsible for the accumulation of the related natural products. When plants are stressed, secondary metabolites production may increase because growth is often inhibited more than photosynthesis, and the carbon fixed is predominantly allocated to secondary metabolites. Nutrient stress also has a marked effect on phenolic levels in plant tissues. Deficiencies in nitrogen and phosphate lead to the accumulation of phenyl propanoids and lignification (Ramakrishna and Ravishankar, 2011).

The study findings tend to be in line with previous research. For instance, the total polyphenols content for the amaranth cultivar seeds were in agreement with recently published data (Gorinstein et al., 2008; Repo-Carrasco et al., 2010; Nana et al., 2012). Other studies suggested somewhat higher polyphenols content (Vollmannová et al., 2003; Alvarez-Jubete et al., 2010; Okarter, 2012; AkinIdowu et al., 2017), which might be accounted for by differences in the fertilization and irrigation treatments, cultivars or pedoclimatic conditions. Similarly, our study findings on flavonoids content were lower than those reported by some studies (Czerwinski et al., 2004; Nana et al., 2012), but higher than reported by other studies (Paśko et al., 2008). These differences were possibly due to differences in environmental factors or variance within the cultivars of Amaranthus species (Steffensen et al., 2011). Our findings that total flavonoids content revealed no significant differences among species in contrast to total polyphenols, but significant differences among cultivars within species, are in agreement with those obtained by other authors (Akin-Idowu et al., 2017), who also reported the same polyphenols and flavonoids range between Amaranthus hypochondriacus and Amaranthus cruenthus. In a recent study, 18 different amaranth cultivars appertaining to four amaranth species were cultivated in parallel in Argentina, Mexico, Spain and two different locations in the Czech Republic. Based on the obtained results the authors concluded that flavonoids showed large variation that were influenced mainly by environmental conditions, but some flavonoids, especially rutin, also exhibit strong variations between the cultivars (Steffensen et al., 2011).

In our study there was also evidence for notable differences between ABTS and CUPRAC assays regarding antioxidant activity assessment for the four studied amaranth cultivars. This could be partly due to the ABTS method representing a mixed hydrogen atom transfer (HAT)/ET-based assay (Alpinar et al., 2009; Apak et al., 2013). Although ABTS assay is usually classified as an ETbased method, the HAT mechanism also applies (Zhong et al., 2015). Antioxidants can neutralize the radical cation $\mathrm{ABTS}+$ generated from ABTS, by either direct reduction via electron donation or by radical quenching via hydrogen atom donation, and balance of these two mechanisms is generally determinate by antioxidant structure and $\mathrm{pH}$ of the medium (Huang et al., 2005). Our data are also consistent with those of other studies that reported similar results for related edible crops, including kiwifruit. Park et al. (2006) acknowledged that the CUPRAC and total polyphenols measurement results in the extract of kiwifruit correlated strongly $\left(r^{2}=0.81\right)$, which is superior to other antioxidant capacity assays such the ABTS. Another study (Alpinar et al., 2009) reported that the TEAC order for phenolic acids of CUPRAC is reverse than that of ABTS. This may be the reason of the significant differences between the CUPRAC and ABTS results of amaranth cultivars.

Previous research by Matuz et al. (2000) using Amaranthus molerosa grains reported that amaranth had $15.4 \%$ protein of a favourable amino acid composition with the highest content of Met, Lys, and Arg. Also, Oyedeji et al. (2014) reported protein content of between $15.23 \%$ and 16.47\% within Amaranthus bybridus while Pospišil et al. (2006) reported protein content of between $16.3 \%$ and $16.7 \%$ in Amaranthus cruentus and between $16.2 \%$ and $17.4 \%$ in Amaranthus bypochondriacus. Our study results obtained for 'Amont' cultivar, which belongs to Amaranthus cruentus species (average protein content of $21.43 \%$ ), are supportive of the earlier research.

The higher protein content obtained in the amaranth cultivars grown with manure fertilizer is consistent with the results of previous research (Adekayode et al., 2004; Oyedeji et al., 2014). Fermented manure fertilizer contains useful soil nutrients that are necessary for the plant growth. This possibly accounted for higher performance of NF than the control (NN) and IN planting conditions. Moreover, the study cultivation year was a rainy one and the irrigation could be considered a stress factor for grain amaranth protein production. Mlakar et al. (2012) found that there were higher protein amount in amaranth grains for treatments where nitrogen was applied. An insignificant 
response pattern in protein concentration of some amaranth species was reported by Pospisil et al. (2006), who conducted field experiments with the same amaranth species (Amaranthus cruentus and Amatanthus hypochondriacus), in Croatia. On the other hand, Elbehri et al. (1993) reported a linear increase of protein concentration in amaranth grain when nitrogen was applied.

\section{Conclusions}

Our study identified substantial differences in polyphenols, proteins, and antioxidant activity of amaranth seeds appeared to vary with irrigation/fertilization interventions, and cultivar. According to the recent EU guidelines on reducing agricultural crops vulnerability to draught under current climate changes, it was recommended the use of cultivars best adapted to high temperature and lower annual rainfall across the EU. Our study findings recommend 'Plenitude' and 'Hopi Red Dye' cultivars as valuable grain amaranth choices with regards to polyphenols, protein, and antioxidant activity properties. In addition, organic fertilization caused a significant increase in phenolic compounds and protein for all the studied cultivars, recommending fertilization as an important condition to enhance amaranth seeds nutritional value. The applied methods have shown that amaranth seeds have high content of protein or polyphenols, with high antioxidant activity and could represent potential alternatives to cereals in case of certain pathologies. Whether similar results are obtained under different planting conditions or across different EU countries required future investigations, using this study methodology.

\section{Conflict of Interest}

The authors declare that there are no conflicts of interest related to this article.

\section{References}

Adekayode FO (2004). The use of manure to increase the yield and quality of amaranthus to feed rabbit in a humid tropical region. Journal of Animal and Veterinary Advances3(11):758-762.

Akin-Idowu PE, Ademoyegun OT, Olagunju YO, Aduloju AO, Adebo UG (2017). Phytochemical content and antioxidant activity of five grain amaranth species. American Journal of Food Science and Technology 5(6):249-255.

Alonso-Miravalles L, O'Mahony JA (2018). Composition, protein profile and rheological properties of pseudocereal-based protein-rich ingredients. Foods 7(5):1-17.

Alpinar K, Özyürek M, Kolak U, Güçü K, Aras Ç, Altun M, ... Apak R (2009). Antioxidant capacities of some food plants wildly grown in Ayvalik of Turkey. Food Science and Technology Research 15(1):5964.

Alvarez-Jubete L, Wijngaard H, ArendtEK, Gallagher E(2010). Polyphenol composition and in vitro antioxidant activity of amaranth, quinoa buckwheat and wheat as affected by sprouting and baking. Food
Chemistry 119(2):770-778.

Apak R, Gorinstein S, Böhm V, Schaich Karen M, Özyürek M, Güçlü K (2013). Methods of measurement and evaluation of natural antioxidant capacity/activity (IUPAC Technical Report). Pure and Applied Chemistry 85(5):957-998.

Berger A, Monnard I, Dionisi F, Gumy D, Hayes KC, Lambelet P (2003). Cholesterol-lowering properties of amaranth flakes, crude and refined oils in hamsters. Food Chemistry 81(1):119-124.

Çekiç SD, Başkan KS, Tütem E, Apak R (2009). Modified cupric reducing antioxidant capacity (CUPRAC) assay for measuring the antioxidant capacities of thiol-containing proteins in admixture with polyphenols. Talanta79(2):344-351.

Czerwinski J, Bartnikowska E, Leontowicz H, Lange E, Leontowicz M, Katrich E, ... Gorinsteine S (2004). Oat (Avena sativa L.) and amaranth (Amaranthus hypochondriacus) meals positively affect plasma lipid profile in rats fed cholesterol-containing diets. The Journal of Nutritional Biochemistry 15(10):622-629.

Elbehri A, Putnam DH, Schmitt M (1993). Nitrogen fertilizer and cultivar effects on yield and nitrogen-use efficiency of grain amaranth. Agronomy Journal 85(1):120-128.

Gorinstein S, Pawelzik E, Delgado-Licon E, Haruenkit R, Weisz M, Trakhtenberg S (2002). Characterization of pseudocereal and cereal proteins by protein and amino acid analyses. Journal of the science of food and agriculture 82(8):886-981.

Gorinstein S, Lojek A, Číž M, PawelzikE, Delgado-Licon E, Medina OJ, ... Goshev I (2008). Comparison of composition and antioxidant capacity of some cereals and pseudocereals. International Journal of Food Science \&Technology 43(4):629-637.

Hlinková A, Bednárová A, Havrlentová M, Šupová J, Čičová I (2013). Evaluation of fatty acid composition among selected amaranth grains grown in two consecutive years. Biologia 68(4):641-650.

Huang D, Boxin Ou, Prior RL (2005). The chemistry behind antioxidant capacity assays. Journal of Agricultural and Food Chemistry 53(6):18411856.

Kim D-O, Jeong SW, Lee CY (2003). Antioxidant capacity of phenolic phytochemicals from various cultivars of plums. Food Chemistry 81(3):321-326.

Law-Ogbomo KE, Ajayi SO (2009). Growth and yield performance of Amaranthus cruentus influenced by planting density and poultry manure application. Notulae Botanicae Horti Agrobotanici ClujNapoca 37(1): 195-199.

Lopez VR, Razzeto GS, Gimenez MS, Escudero NL (2011). Antioxidant properties of Amaranthus hypochondriacus seeds and their effect on the liver of alcohol-treated rats. Plant Foods for Human Nutrition 66(2):157-162.

Matuz J, Bartók T, Mórocz-Salamon K, Bóna L (2000). Structure and potential allergenic character of cereal proteins: I. Protein content and amino acid composition. Cereal Research Communications 28(3):263270.

Martirosyan DM, Miroshnichenko LA, Kulakova SN, Pogojeva AV, Zoloedov VI (2007). Amaranth oil application for coronary heart disease and hypertension. Lipids in Health andDisease 6(1):1-12.

Mlakar SG, Jakop M, Turinek M, Robačer M, Bavec M, Franc Bavec 
1160

(2012). Protein concentration and amino acid composition in grain amaranth (Amaranthus cruentus L.) as affected by sowing date and nitrogen fertilization. African Journal of Agricultural Research 7(37):5238-5246.

Nana FW, Hilou A, Millogo JF, Nacoulma OG (2012). Phytochemical composition, antioxidant and xanthine oxidase inhibitory activities of Amaranthus cruentus L. and Amaranthus bybridus L. extracts. Pharmaceuticals 5(6):613-628.

Okarter N (2012). Phenolic compounds from the insoluble-bound fraction of whole grains do not have any celular antioxidant activity. Live Science and Medicine Research 1:1-10.

Oyedeji S, Animasaun DA, Bello AA, Agboola OO (2014). Effect of NPK and poultry manure on growth, yield, and proximate composition of three amaranths. Journal of Botany 828750.

Park Y-S, Jung S-T, Kang S-G, Delgado-Licon E, Katrich E, Tashma Z, ... Gorinstein S (2006). Effect of ethylene treatment on kiwifruit bioactivity. Plant Foods for Human Nutrition 61(3):151-156.

Paśko P, Bartoń H,Zagrodzki P, Gorinstein S, Fołta M,ZachwiejaZ (2009). Anthocyanins, total polyphenols and antioxidant activity in amaranth and quinoa seeds and sprouts during their growth. Food Chemistry 115(3):994998.

Paśko P, Sajewicz M, Gorinstein S, Zachwieja Z (2008). Analysis of selected phenolic acids and flavonoids in Amaranthus cruentus and Chenopodium quinoa seeds and sprouts. Acta Chromatographica 20(4):661-672.

Peiguo G, Al-Khatib K (2003). Temperature effects on germination and growth of redroot pigweed (Amaranthus retroflexus), palmer amaranth (Amaranthus palmeri), and common waterhemp (Amaranthus rudis). Weed Science 51(6):869-875.

Perales-Sánchez JXK, Reyes-Moreno C, Gómez-Favela MA, Milán-Carrillo J, Cuevas-Rodríguez EO, Valdez-Ortiz A, Gutiérrez-Dorado R (2014). Increasing the antioxidant activity, total phenolic and flavonoid contents by optimizing the germination conditions of amaranth seeds. Plant Foods for Human Nutrition 69(3):196-202.

Pospišil A, Pospišil M, Varga B, Svečnjak Z (2006). Grain yield and protein concentration of two amaranth species (Amaranthus spp.) as influenced by the nitrogen fertilization. European Journal of Agronomy 25(3):250253.

Prakash D, Pal M (1991). Nutritional and antinutritional composition of vegetable and grain amaranth leaves. Journal of the Science of Food and Agriculture 57(4):573-583.
Rabie MA, Soliman AZ, Diaconeasa ZS, Bele C (2015). Effect of pasteurization and shelflife on the physicochemical properties of physalis (Physalis perwiana L.) juice. Journal of Food Processing and Preservation 39(6):1051-1060.

Ramakrishna A, Ravishankar GA (2011). Influence of abiotic stress signals on secondary metabolites in plants. Plant signaling and Behavior 6(11):1720-1731.

Repo-Carrasco-Valencia R, Hellström JK, Pihlava JM, Mattila PH (2010). Flavonoids and other phenolic compounds in Andean indigenous grains: quinoa (Chenopodium quinoa), kañiwa (Chenopodium pallidicaule) and kiwicha (Amaranthus caudatus). Food Chemistry 120(1):128-133.

Shamloo M, Babawale EA, Furtado A, Henry RJ, Eck PK, Jones PJH (2017). Effects of genotype and temperature on accumulation of plant secondary metabolites in Canadian and Australian wheat grown under controlled environments. Scientific Reports 7(1):1-13.

Singleton VL, Orthofer R, Lamuela-Raventós RM (1999). [14] Analysis of total phenols and other oxidation substrates and antioxidants by means of Folin-Ciocalteu reagent. Methods in Enzymology 299(152):152178.

Steffensen SK, Rinnan Å, Mortensen AG, Laursen B, de Troiani RM, Noellemeyer EJ, ... Fomsgaard IS (2011). Variations in the polyphenol content of seeds of field grown Amaranthus genotypes. Food Chemistry 129(1):131-138.

Vollmannová A, Margitanová E, Tóth T, Timoracká M, Urminská D, Bojňanská T, Čičová I (2013). Cultivar influence on total polyphenol and rutin contents and total antioxidant capacity in buckwheat, amaranth, and quinoa seeds. Czech Journal of Food Science 31(6):589595 .

Venskutonis PR, Kraujalis P (2013). Nutritional components of amaranth seeds and vegetables: a review on composition, properties, and uses. Comprehensive Reviews in Food Science and Food Safety 12(4):381412.

Zhong Y, Shahidi F (2015). Methods for the assessment of antioxidant activity in foods. In: Handbook of Antioxidants for Food Preservation. Woodhead Publishing Series in Food Science, Technology and Nutrition pp 287-333. 